\title{
An Analytical Study of Muslim Jurists' Opinion Regarding Sunnah
}

\author{
Dr. Hafiz Muhammad Khan ${ }^{1}$ \\ Dr. Shabbir Hussain ${ }^{2}$
}

ISSN (P) 2664-0031 (E) 2664-0023

Received: January 17,2021

Accepted: February 22, 2021

DOI: https://doi.org/10.37605/fahmiislam.v4i1.233

Published: June 30,2021

\begin{abstract}
Islam is such a comprehensive, all-inclusive and basically a socialist religion, which has declared, it as an obligatory to achieve what the society needs and the factors which can be a barrier to social development, are forbidden and affixed as Haram (illegal) by Islam. In this regard after Holy Quran, Sunnah is the key to solve the problems of Muslim Ummah, which opens the door for humanity to look on that how can the obligations and prohibitions occurring in each age and time can be resolved. As for as, the analytical work of Sunnah literature is concerned it is a very high contribution in the field of Hadith and in this article titled "An analytical study of Muslim Jurist's opinion regarding Sunnah", it has been reviewed on that how the Sunnah has ever been a valuable and perpetual attraction from the beginning in Islamic law, due to different aspects. The term Sunnah, which is denoted as الطريقى المسلوكى (a fixed way) applied by the prophet as a legal term what HE any of the above correlated meanings irrespective of whether the way of life custom and conduct are merely acceptable, commendable or detestable and unacceptable ones. Exemplifying the polarizing usage the prophetic tradition, reads: "whoever initiates (or revives) a meritorious Sunnah, within the frame work of Islam shall in addition to reward of intimating that particular Sunnah be endowed with the reward those who would follow his example until the day of resurrection without this diminishing in least from their sins.'In spite of the fact that the term Sunnah is technically used to contribute both good and bad conducts, it is commonly used in the context of good and acceptable way. However, in this study it has also been focused on the road map and guidelines for the Muslim community as a whole and for Jurists as a very essential.
\end{abstract}

Keywords: Analytical, classification, Jurists, khabar, linguists, Sunnah

\footnotetext{
Associate Professor Islamic Studies Department Muhi-ud-din Islamic University Nerian Sharif Azad Jamu \& Kashmir.

2 Assistant Professor Islamic Studies Department Muhi-ud-din Islamic University Nerian Sharif Azad Jamu \& Kashmir.
} 


\section{The Authority}

The prophet is the authorized personality from Allah the most high to the mankind all over the world as expressed and defined in Quran. His mission is thus stated in the Quran "we revealed to the reminder that you make clear to men that which has been revealed to them that happily they may reflect" ".This statement implies the prophet's highest authority in the interpretation of the Holy Book, be it by words or by action that this consultant is binding force between all Muslims and it is explicitly declared by Quran: whoever obeys the Messenger

\section{Legal Usage}

Literally the term Sunnah is used in Arabic language in the following context:

- Way of life

- Custom

- Behavior or conduct

As a legal term, Sunnah has also different connotations depending upon the usage of the term in different sciences of Islam:

1. Sunnah is used as opposite of Bidah (innovation) thus, whoever sticks to the principles of Islam is said to be following the Sunnah or the right path of Islam-in contrast to those who dissent.

2. Sunnah is also used to denote conformity with consensus of Muslim community as against a minority point of view; irrespective of whether such consensus is based on the Sunnah of the prophet Quran, Qiyas , public interest of " $U r f$ "(custom) etc.

3. According to narrators Sunnah comprises whatever may pertain to the prophet hence the sayings, deeds and tacit approvals of prophet as well as description of physical features and moral behavior are treated as Sunnah and accordingly compiled in book of Hadith

\section{Classification of Sunnah as Expressed by the Prophet}

Sunnah is classified in different ways and manners depending on the various angles from which one approaches such a far-reaching subject. However, with regard to the manner by which the Prophet (expressed the Sunnah, it is classified into: Al- Sunnah al-Quwliyyh, Al-Sunnah al-fi'liyyah and AlSunnah al-Taqririyyah. 


\section{Al-Sunnah al-Quwliyyah}

Al-Sunnah al-Quwliyyah corresponds to the sayings of the Prophet been stated before that Sunnah, like the Quran is revelation. However, unlike the Quran the Sunnah was expressed in the words of the Prophet whereas the Quran is the very utterances of Allah Exalted be He. Consequently, the sayings of the prophet relating to the different walks of human existence, death and resurrection comprise what is known as AlSunnah al-Quwiyyah, so long as that saying is relating to fulfillment of his holy mission as the last Messenger of Allah to mankind. The following is an account of this type of the Sunnah:

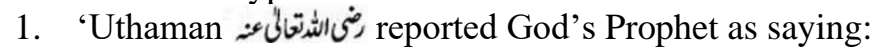

The greatest among you is he who learns and teaches the Quran. ${ }^{3}$

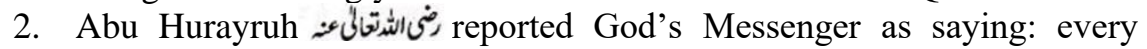
Prophet has a supplication which receives an answer but whereas every prophet made his supplication in this world, I have kept mine till the Day of Resurrection to be used in intercession for my people, and if God will, it will reaches those of my people who have died without associating anything with God. ${ }^{4}$

3. Hakim b. Hizam stated Allah's Prophet as saying: Both parties in a trade deal have the rights to annuli it as long as they are in the same contractual session (Majlis al-Aqd).and if they say the truth and make everything pure they will be blessed in their transaction but if they tell a lie and conceal anything, blessing on their transaction will be blotted out. ${ }^{5}$

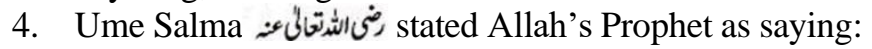

You bring to me (for judgment) your disputes. Few of you may perhaps be more powerful in their appeal than others; so I give decision on their behalf according to what I hear from them. (Tolerance in mind, in my decision) if I share any thing for him from the right of his brother he should not accept that, for I sliced off for him a some part from the Hell. ${ }^{6}$

5. It has been described on the authority of Ibi Musa that when the Prophet of Allah delgated any of his friends on a mission he would say: Give tiding (to the people), do not create (in their minds) aversion (towards religion); show them mercy and do not be rigid upon them. ${ }^{7}$

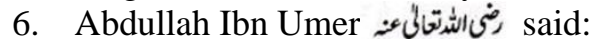

"I asked the Prophet which act is loved most by Allah|? He answered; "To offer prayers at their early (very first) stated times". Abdullah asked, "What is the next (in goodness)? The Prophet said, "to contribute in Jihad for Allah's cause". Abdullah added, "the Prophet narrated to me these three things and if I had asked him more, he would have told me more." $"$ 


\section{Al-Sunnah al-F'-liyyah}

Al-Sunnah al-Fi'liyyah represents the deeds and practices of the Prophet which have religious bearing. These acts and practices had been portrayed and transmitted by the companions of the Prophet and their successors (Al-Tabi'in). Much as the sayings of the Prophet have a binding force upon Muslims so as his practices. The following traditions may exemplify al-Sunnah al-Fi' liyyah

1. Abu Hurairah رنى narrated that:

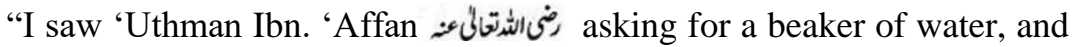
when it was carried he poured water over his hands and washed them thrice and then put his right hand in the water flask and washed his face and washed his mouth, washed his nose by drawing in water and then blowing it out. Then he washed his face and fore-arms up to the elbows thrice, passed his wet hand over his head and washed his feet up to the ankles thrice. Then he said, "I heard Allah's Apostle saying, "if anyone makes ablution like that of mine and offers a two -raka'at prayer during which he does not think of anything else (not related to the present prayer) then his past sins will be forgiven. After performing the ablution 'Uthman صنىالشرتالكن said, I am going to tell you a Hadith which I would not have told you, had I not been compelled by a certain Holy verse (the sub-narrator 'Urwa) said this verses is, "Those who conceal the clear signs we have sent. I hear the Prophet saying, "If anybody performs ablution perfectly and offer the compulsory prayer Allah will certainly forgive his sins committed between that ablution and the offering of the next prayer." 9

2. Muhammad Ibn 'Umar Ibn. 'Ata' رنى الشرتالكغخ narrated that: "I was sitting with some of thefriends of the Prophet and the prayer of the Prophet

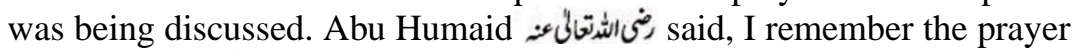
of the Prophet better than anyone of you. I saw him raising both his hands up to the close of the shoulders on saying the Takbir, and on bowing he placed his hands on both knees and bent his back straight, then he stood up straight from bowing till all the vertebrae took their normal positions. In worships, he placed both his hands on the ground with the forearms away from the ground and away from his body, and his toes were facing the Qiblaw. On sitting in the second Rak's he sat on his left foot and supported up the right one; and in the last Rak'a he pushed his left foot forward and kept the other foot supported up and sat over the buttocks."10

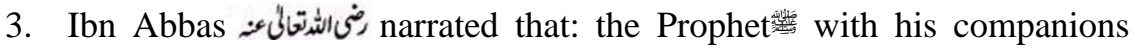
started the Journey (for Hajj) from Medina after combing and oiling his hair and putting on two sheets of Ihram (upper body cover and waist 
cover). He did not stop anyone to wear any kind of sheets except the ones colored with saffron because they may leave the scent on the skin.

And so in the early morning, the Prophet mounted his mount while in Dhul-Hulaifa and set out till they reached Baida', where he and his friends recited takbeer on their cattle for Taqlid (which means to put the colored garlands around necks of the Budin - camels for sacrifice). And all that happened on th $25^{\text {th }}$ of Dhul-Qa'ida. And when he reached Mekkah on the $4^{\text {th }}$ of Dhul - Hijja he performed the Tawaf round the Ka'ba and did the Tawaf between the Safa and Marwa. And as he had the Budns, which he had garlanded, he did not release himself from his Ihram. He proceeded towards the supreme places of Mekkah near Al-Hujun and he was assuming the Ihram for Hajj and did not go near the $K a$ 'ba after he performed Tawaf till he returned from 'Arafat. Then he ordered his friends to doTawaf round the $K a ' b a$ and then the sa'yee (running) between Safa and Marwa, and to cut short the hair of their heads and to release themselves from Ihram. And that was only for those people who had not had garlanded Budn. Those who had their wives with them were permitted to have access to them and similarly fragrance and wear ordinary clothes were made acceptable for them. ${ }^{11}$

\section{Prophetic Deeds}

In the absence of any clear saying or proof to the contrary, the deeds of the Prophet generally signify permission (Idhn). However, Idhn is a general and wide term, which ranges from obligatory (wajib) act, across Mubah (Permissible) acts to Mundub (commendable) acts. While the desertion (Tark) of an act by the Prophet also ranges from absolute prohibition to merely signifying that leaving such an act is better than doing it as will be illustrated herein.

1. The abstinence of the Prophet from doing an act may indicate that there was apprehension that it may entail some injustices. This is exemplified by his refusal to witness the gift made by one grantor to one of his children. The man said, "No." then the Prophet said to him, "Try to find another person to witness that for I do not witness an act injustice."12

2. His abstinence may be for the sake of others. The Prophet was so lenient merciful and considerate. He used to withhold doing a thing for the mere fear that it might harm others and/or cause some hardships to his community.

(i) He used not to eat onion for the sake of the angels.

(ii) He did not continue leading his companions with Tarawih during the nights of the month of Ramzan for fear that it might be compulsory for them. 
(iii) More so the Prophet used to cease doing a thing in spite of its usefulness just for fear being of misinterpreted and hence resulted in

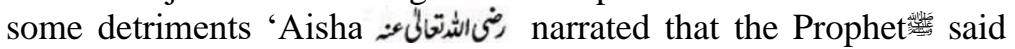
to her, 'Had it not been for the fact that your people have recently emerged from their jahiliyyah (period of religious ignorance and hence they would not appreciate and accept whole heartedly my deed) I would have rebuilt the $K a$ 'ba on the example of Ibrahim."13

Similarly, he abstained from punishing the hypocrites-for apparently adhering to the rules of shari'ah so that people may not propagate that Mohammad killed his followers.' 14

Finally the Prophet may resist from doing a thing which is Mubah permissible - due to a temperamental dislike. For instance he approved the eating by Sayyidna Khalid; yet, he added that, 'such is neither prevalent in my environment nor known by my people so I dislike it' 15

The Prophetic traditions therefore have to be construed in the light of the aforementioned connotations and the other surrounding circumstances and causes which are deemed relevant to its understanding.

\section{Al - Sunnah al-Taqririyyah}

These are the tacit approvals of the Prophet. As a human being, the Prophet was expected to express and accordingly convey his message by verbal word (his sayings practical implementations his deeds or by mere) silence (tacit approval). That if an act or saying which involved a legal rule was said or done in his presence the Prophet was duty-bound to explain and make clear the legal stand of Islam in respect of that. Allah Most Merciful commands him as follows.

O messenger, convey to the people whatever has been sent down to you from your Lord for if you do not do this you will not be doing justice to his message practical implementations (his deeds) or by mere. ${ }^{16}$

Hence, when an act was done or said in his presence or brought to his information and he, never-the-less, kept silent, his silence is deemed to be an approval of that particular act or saying: as such the silence of the Prophet connotes that such is a permissible $(M u b a h)$ or legal act for it does not behave the Prophet to close an eye or turn a deaf ear to wrong deeds. To say otherwise would delay a duty from its prescribed time which is unacceptable from Allah's Messengers. ${ }^{17}$ 
In the light of this the Muslim jurists established the following maxim. 'That when expression is a must, silence is deemed expressive. ${ }^{18}$

The following are some examples of the tacit approvals of the Prophet

1. Once the Prophet sent an expedition to BaniQuraidha. He told them, 'that none of you should pray the ' $A$ 's $r$ except at (the place of) BaniQuraididha; some companions adhered strictly to the letter of the Prophetic command and hence they delayed al-Asir prayer till after sunsent. While another groupconvened that the Prophet wanted us to move quickly and without delay to BaniQuraidha and he did not intend that we should delay the prayer. So, they prayed in time. When they returned from the expedition and informed the Prophet he approved the Ijitihad of both group." 19

2. Also once Sayyidina Khalid رنى ate a meat of reptile in the presence of the Prophet. The Prophet did not express any view and hence jurists concluded that it is permissible to eat.

This category of the Sunnah is not as abundant as the first two ones. it seems that there are few clear examples for it. Most of the examples cited by jurists are followed by either a saying or an action from the Prophet asked

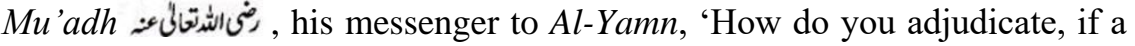
case is brought before you? Mu'adh said, 'I will adjudicate in accordance with the Qura'an. 'Then the Prophet said what if you do not find a rule in

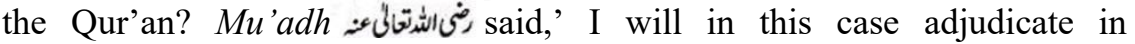
accordance with the Sunnah of the Prophet said, what if, you do not even find a rule in the Sunnah? Mu'adh ivى said, 'Under such a circumstance I will resort to ijtihad in which I will do my utmost best,' thereupon, the Prophet was so pleased he patted on his chest and said, 'Praise be to Allah who guided the Messenger of the Allah to what praise be to Allah and his Messenger.'20

It is crystal clear that the Prophet approved the procedure that had been prescribed by Sayyidna Mu'adh رنىالشترأقع: but his approval is not only a tacit one, because he expressed it in both action and words.

Also, while two companions were on a journey, they faced short of water. When it was time for prayer, they performed Tayamum and prayed. However, they got water before the expiry of the time of that prayer. One of them performed ablution and repeated his prayer while the other did not. When they were back home they informed the Prophet. The Prophet said to the one who did not repeat the prayer, 'you have done according to the 
Sunnah. And he said to the one who repeated the prayer, "you would have your reward twice." 21

Although the Prophet confirmed the ijtihad of both of them, yet his confirmation is an explicit one.

\section{Hadith, Khabar and Athar}

Despite some technical differences, the above terms are in most cases used interchangeably. In one context the term Hadith is synonymous to the term Sunnah which comprises the sayings, deeds and tacit approval of the Prophet. But Hadith is equally used to stand for al-Sunnahal-Quwliyyah. Perhaps this is because the literal meaning of the term Hadith corresponds to the sayings but to the deeds and tacit approval.

Also the words Hadith and Khabar are literally used interchangeably. But technically Hadith stands for Sunnah according to the consensus of jurists, while Khabar is some time used for Sunnah some traditionalist have, however drawn a distinction between Hadith and khabar. They considered a narration which finally rests on the authority of the Prophet as a Hadith whereas on the authority of the companion as a Khabar. For this reason a person who is specialized in Sunnah is called a Muhaddith (traditionalist), while the one who is specialized in history as Akhbari (historian) the jurist of Khurasan used the term Athar has been used in this context to distinguish between the connected chain of narration and a disconnected one.

The Prophet, however in order to avoid a possible confusion of his sayings with Quranic texts did not encourage his Companions to write down what he said. But this did not affect the status of the Sunnah; it only rendered more difficult to its later recording. The difficulty was the price Muslims had to pay for keeping their Holy Book unquestionably authentic and unique. Such a difficulty, indeed, is a result of the basic separation between the Quran which is the letter and spirit of God's Will, and the Sunnah, which is the human, though prophetic, clarification of the Quran by Muhammad. The latter, by virtue of its very nature, was meant to make the Revelation, through a man, clear to men. ${ }^{22}$ Therefore, it was no great risk to leave the recording of the Sunnah for a later authentication by the Faithful. Muhammad's formidable influence and authority, not only on individual Muslims but also on the actual shaping of their entire society, were strong enough to enable later generations of Muslims to verify what Muhammad had said or done. One of the means of verification was the faculty of memory - a noteworthy characteristic of the Arabs-particularly strong when whetted by the urge of faith and spiritual love. ${ }^{23}$ 
"The characteristic religious activity, then, of the first century," says Gibb, "was the collection and transmission of details about the life and actions of Muhammad ... In view of the profound impress which the personality of the Prophet had left on his adherents, this activity was a spontaneous growth, owing nothing to outside influences. The natural center of these studies was Medina, where most of the companions continued to live and where firsthand information was most securely to be found."

But soon after this statement, a confusion between "Sunnah" in its Arabic literal meaning and "Sunnah" as a a legal term seems to obscure the course of Prof. Gibbs's analysis. While excluding the "Written Book" form the orbit of the "Sunnah," which is correct, he defines the latter as the selfdeveloped tradition of the Muslim community, including all its social and legal usages "whether these were taken over from older custom or were set by the Prophet." 24

As a proof, he interprets the designation "AhlulSunnah" or Sunnis" which applies to "orthodox" Muslims as against the "Shiah" or the "partisans" of Ali - as implying the adherence to the "usage of the community," and not to the "usage of Prophet," which the Shiah also claim to share. But how could he conceive that the Shi'ah also did not equally claim their adherence to the usage of the community? Is it because they were the minority? And if it is a numerical measure that determines the usage of the community, then on what basis does his differentiation rest when he himself says on the same page that (for most Sunnis the two were identical)?

This confusion prevails in most non-Muslim writings on the subject. Prof, Schacht For instance, bases his opinion on similar conclusions. ${ }^{25}$ Another example is Prof. Alfred Guillaume, who shares this confusion with astonishing ease ${ }^{26}$ Prof. Khadduri not only follows in the footsteps of these Western predecessors, but further brings a new definition of the Sunnah which has nothing to do with what all Muslims understand by it. ${ }^{27}$

The reasons behind this confusion can be epitomized by two important facts:

1. According to our early definition of the Sunnah, which is common to all Muslim schools of law, it includes what the Prophet said, did or agreed to. This latter category has been an open door for confusion, as well as for strong suspicion as to authenticity of Sunnah. Anything of utility that did not contradict a principle of Islam was accepted and sanctioned by the Prophet, and it thus became a part of this Sunnah. Western students of the Sunnah, however failing to comprehend this aspect of Prophetic legalization and realizing that a specific deed or institution thus 
legalized did exist before the Prophet are either to define the Sunnah as "the usage of the community," as said Prof. Gibb or to suspect that forgeries have infiltrated into it . A good example of this attitude is that of Kenneth Cragg in the Call of the Minaret. He says: "Much came into the Muslim heritage of obedience in this way from the customs and cultures of the conquered territories. Muhammad became the posthumous repository of many ideas and practices which Islam had neither will nor power to eradicate from the behavior of its new devotees. But there is little evidence that elements incompatible with crucial Muslim teachings found any such entity... The fact that things must be believed to turn upon prophetic precedent is no more than a measure of the veneration in which revelation and its agent were regarded." ${ }^{28}$ This last sentence not only implies a self deceiving measure of veneration which would not even shrink from forgery but also displays a grave misconception of the basic characteristics of legalization in both Quran and Sunnah as we shall see later, it is an accepted principle in Islamic Law that everything is allowed unless explicitly prohibited, and not the other way round. Muslims, therefore, do not need Prophetic precedents this false assumption of forgery, as regards both its supposed justification and in its positive value.

We also include among the reasons underlying this confusion the repeated allegation concerning the influence of Roman Law on Islamic Law. Prof. Nallino, the famous orientalist, in his lecture at the international Congress of Roman Law held in Rome in 1933, ${ }^{29}$ stated that Dominico Gatteschi was the first to claim the existence of such an influence in his book Manuale di diritto pubblico e private ottomano (Alexandria, 1865). He was an advocate who lived in Alexandria, but knew neither Arabic nor Turkish. In this book he presumed that the introduction of Roman norms into Islam had been facilitated by disguising these Roman norms in the garb of apocryphal sayings attributed to Muhammad. Since that time, many others have been repeating the same allegation, with an infinite variety of nuances, and elaborating thereon. Prof. Dawlibi, in his book on Roman law, ${ }^{30}$ mentions Santillana, Goldziher and Masse as opening to the same effect. He then deals at length with their arguments. Both Nallino and Dawalibi not only exposed the charge as baseless but further proved its inevitable contradiction with several judicial and historical facts. Prof. Gibb states, "The principles upon which Islamic Law was constructed and-one may even say the whole spirit of its application were entirely unrelated to those of the Roman jurists." 31

2. Another reason for the confusion about the Sunnah is the fact that its study has, in the course of time, become a special science and, thus, a 
kind of "specialization" has been increasingly demanded as a basis for its utilization as an authentic reference. In the first century of Islam, as Prof. Gibb has remarked, the collection and transmission of details about the life and the actions of Muhammad was "a spontaneous growth" and "first-hand information was mostly securely to be found." Thus, for an early Muslim there was no problem in keeping to the Traditions of his Prophet. Actual adherence, devotion and memory had been strong guarantees for the authority and authenticity of the Sunnah. But gradually the strong hold of Islam became attenuated and preIslamic schism began to breath again after a along period of suppression sometimes in the name of Islam itself. Political maneuvers and intrigues became active in Muslim society. A seemingly easy instrument for playing religious sentiments as well as for destroying the very framework of Islam was the Sunnah. Deliberate forgeries were instituted and many false saying were ascribed to the Prophet. The counterbalance against such forgeries however was in twofold:

A. In the first place, there were the recorded compilations of the Sunnah by early Muslims, some of which were written down in the presence of Prophet himself. Some examples are

i. The most import sermon of Muhammad on the day of the conquest of Makkah, which he ordered to be recorded in response to the request of a Muslim from yemen. ${ }^{32}$

ii. The private record of Abdullah Ib 'Amr Ibn al-'As, a Companion of the Prophet. He called this record Al-Sadiqah, which means "The truthful." It was later incorporated in the authoritative books of Hadith. ${ }^{33} \mathrm{He}$ said, "Written here is only what I did hear with my own ears from the Prophet" ${ }^{34} \mathrm{Ab}$ Hurayrah, a reputed authority on Hadith, said, "none is better keeper and relater of Hadith than me, except Abdullah Ibn'Amr Ibn al-'As. That is because he used to write whatever he heard from Prophet." 35

iii. Anas Ibn Malik, the devout servant who lived with the Prophet all though his stay in Madinah, and who died as late as the year $93 \mathrm{H}$, said: "Every now and then I took down in notes interesting points from what the Prophet said in his discourses and other occasions of conversation; and I used to read these notes over to the Prophet whenever I found him having leisure, and after he had corrected them, I made a fair copy of them for my own record" 36 We later see a full chapter under the name "Anas" in the reliable reference book of Al Musnad of Ahmad ibn Hanbal. 
iv. In reliable reference book of Sunnah, written documents dictated by the Prophet are frequently mentioned and authenticated. ${ }^{37}$

v. In his book Al-Wathaiq Al-Siyasiyah (Cairo, 1956), Dr. M. Hamidullah records 250 documents emanating from the prophet and written down in his presence.

These limited examples may serve to present the often ignore fact that the late famous compilations of Hadith were by no means the first written documents relating to the Sunnah.

B. Next to these written documents, as a counter-balance to forgery, were the pronounced works of Muslim researchers in the field of collecting and authentication of the Sunnah. "Each Hadith was thus began by a chain of authorities (Sanad) going back to the original narrator, and the procedure was called "isnad" or "backing". ${ }^{38}$ In the course of time a separate "science of Hadith" was constructed up, whereby not only the chains of authorities could be found out by the Prophet himself, but also the fact based data about all narrators was studied and classified. Says Gibb: "The specific application of this Fact based material to the purposes of hadith-criticism was the object of a special branch of study called the 'science of impingement and justification.' This investigated the bona fides of the guarantors of tradition, their moral character, truthfulness, and powers of memory," 39 Again he says "in the history of Islamic science the discipline of hadith- criticism became more and more meticulous" ${ }^{\prime 40}$

The outcome of all this effort is the classification of every recorded item of the Sunnah according to its status of authenticity. Thereupon stands its authority as a text of Islamic Law. The existence of the science of Hadith makes it impossible for any bona fide Muslim scholar to accept the manner in which most Western writers have been treating the Sunnah. For they, says Prof. Nallino, "have limited themselves to general affirmations: the fruit of calculations of probability rather than profound study." ${ }^{41}$ Prof. VeseyFitzgerald, for instance, refutes a Hadith which has been held authentic by all authorities on the subject, with the easy assumption that "its well-drilled regularity" is that "of a church catechism or a code of law"-and thus "unconvincing." ${ }^{42}$ One has to ask: what, then, would remain of the structure of the Sunnah if one were to exclude from it everything that is characterized by regularity and a sense of law? And what other characteristics would Prof. Vesey-Fitzgerald suggest as a alternative to "well-drilled regularity" which, according to him, is "unconvincing," in order to establish the authenticity of the Sunnah convincingly? These questions are left unanswered, and indeed the more we come across such easy assumptions, the better we realize the 
indispensability of the science of hadith. To our knowledge, there does not exist such an exacting science outside the Muslim world. Even with a fair statement like Prof. Gibb's, describing one work on the subject, Sahih AlBukhari, as "a work of immense interest and scrupulous scholarship," 43 we do understand why non-Muslim scholars fail to find their way through the science of Hadith. Rather, we should not expect them to be able to do so. We often recall the words of Prof. Gibb depicting some works on Hadith- criticism as "hair-splitting" exercise. ${ }^{44}$ Even among Muslims, only very few scholars are specialized on the Sunnah, and these can hardly find time and energy for other subject. To expect more from Western scholars, who write at the same time on "Islamic theology" and "Islamic philosophy" and "Islamic Law" and "Islamic history" and "comparative studies" and" Arabic language," 45 etc is only unfair. But, on the other hand it is also unfair on their part to dismiss such a fully established science as that of Hadith with the easy assumption of forgery - the very thing this science was established to root out or to make arbitrary accusations without a scholarly method of verification.

\section{Sunnah According to Arabic Linguists}

The definition of Sunnah according to Arabic linguists:

1. Ibn-e-duraid (died 321AH) wrote in his book "Aljamhera": "the Sunnah is a way or method" it is said somebody created good and bad ways for people. ${ }^{46}$

2. Abu Nasr Ismail bin Hammadjohary (died 393 AH) said: "the meaning of Sunnah is a way of passing the life in good shape". ${ }^{47}$

3. Abul Hussain Ahmed bin Farris bin Zakriyah(died 395AH) said that "the meaning of Sunnah of Holy prophet

4. Imam Raghib Asfahani (died $506 \mathrm{AH}$ ) said that "the Sunnah of the prophet means the actions and the deeds of Holy prophet and the Sunnah of Almighty Allah means the way of worship in Islam without any change". ${ }^{49}$

5. Allama Zamashry (died 538AH)) said "someone started something good we called it Sunnah and if someone follow that way we called it as he is following and obeying Him. ${ }^{50}$

6. Allama Ibn Al-AseerAljazry (died $606 \mathrm{AH}$ ) said that the Sunnah in Arabic language is "Uswa" the example of life of Holy prophet and his orders of command for Muslims to accept and obey the instructions as ordered..$^{51}$ 


\section{The Sunnah According to Four Schools of Thought}

The four jurists had given special attention towards Sunnah in their rules and usual's in compilation of fiqha.

1. Imam Shafi (died $240 \mathrm{AH}$ ) said "all the Muslims are agreed upon this point that when the Sunnah has been discovered then no one can leave it in any circumstances. ${ }^{52}$

2. Allama Jalal ud-din Sayuti (died 911(AH)) said "the Sunnah that is sayings of the Prophet i drawn from Quran. ${ }^{53}$

3. Imam Malik (died $179 \mathrm{AH}$ ) said "if any opinion is endorsed by Sunnah you should follow it otherwise if opposed by Sunnah leave it". ${ }^{4}$

4. Imam Ahmed bin Hambal (died $242 \mathrm{AH}$ ) said "the person who has rejected the Sunnah of Holy prophet has come to the edge of death". 55

5. The definition of Sunnah according to Muhammad ujaj is "the Sunnah is name of saying, deeds and taqrir. It includes all kinds of "Akhlaq" even before "Nabowah" (Prophet Hood) like worship in cave of Hira and after that and Sunnah in this meaning is parallel to Hadith. ${ }^{56}$

6. The word Sunnah is sometimes used for "bidah" and bidha means "something new" after that bidha is used in terminology of sharia for "sherar-e-Islam" which was not done bay the Holy Prophet or His companions. ${ }^{57}$

7. The above mention explanation is supported by Hadith in which the Prophet said "anybody who created new things in Islam which were not there is unacceptable. ${ }^{58}$

\section{The Sunnah According to Other Jurists}

9. The word Sunnah consists upon the conversation deed and

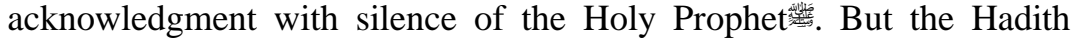
merely attached with utter statement. ${ }^{59}$

10. Whatever speech is spoken by the Prophet is called Sunnah and that are three things which are words deeds and conformation of an action done by the companion in front of the Holy Prophets and He became silent. ${ }^{60}$

11. The Sunnah is according to Muhaddeseen. i.e (expert of Hadith) and the other scholars are called whatever speech, words and approval of an action done by any companions in front of Holy Prophet and the Prophet became silent. Even that is in the capacity as a Prophet or being human. ${ }^{61}$

12. According to the scholars of usual the word Sunnah is applied on the sayings deeds and taqreer of the Holy Prophet, and it is parallel to the Hadith. ${ }^{62}$ 
13. The Sunnah is applied for sayings, deeds and silence of the Holy Prophet over an action of companion and it is also called Hadith, except the Holy Quran. ${ }^{63}$

14. Any action narrated by companions and related to the Holy Prophet is called Sunnah. ${ }^{64}$

15. Any sayings, deeds or silence or an action done by any of His companions to be fall by the Holy Prophet is called Sunnah. ${ }^{65}$

16. The word Sunnah is used for habits in the vocabulary, but in the Islamic shariah this term is for action, deeds and silence of the Holy Prophet upon which He did not expelled from His life practice. ${ }^{66}$

17. In the English language's dictionary, Sunnah means, the perpetually practice of the Holy Prophet to be enacted by His life time and after that time a clear guidance for His Muslims Followers. ${ }^{67}$

18. The affirmation, action and agreement to become silent upon the deeds of His companions is called Sunnah.

So, it is very clear that all Muslims Scholars and jurists are agreed upon the authority of Sunnah of the Holy Prophet with the different opinion with same manners. ${ }^{68}$

19. Sunnah, is the most suitable word than khabar, because the word Sunnah covering the sayings, the deed and the silence of the prophet ${ }^{69}$

20. In the terminology of shariah the sayings, deed and silence of the holy prophet peace be upon Him is called Sunnah ${ }^{70}$

21. Sunnah is applied for sayings, deed and silence of the holy prophet and this is also used for deed and action of companions of the messenger of Allah. ${ }^{71}$

22. The Sunnah is divided in to three kinds and that are the sayings, deed and silence of the holy prophet 72

23. Each and every sentence of the holy prophetwhich was not the Quranis called Sunnah and is narrated by the companions is called Hadith, and Hadith is elucidation of the Holy Quran. ${ }^{73}$

\section{Recommendations and Suggestions}

1. For the well and apposite connotation of Sunnah, the jurits and the scholars must have great skill in the science of Sunnah

2. For presenting and giving comprehensive elaboration of Sunnah, they must have not only the thorough knowledge of it but also have fully proficiency over all the relevant subjects to it.

3. The state of Sunnah must not be taken as secondary in elucidating Islam, even though it is a varied science, it must be scrutinized well.

4. The opinions and views of the jurists of the four school of thoughts regarding Al-Sunnah al-Quwliyyh, Al-Sunnah al-fi'liyyah and Al- 
Sunnah al-Taqririyyah must be given in a way that the people may become aware to its applicable implication.

5. Contemporary Ulemas and Scholars views, elaborations and different opinion with same manners regarding Hadith, Sunnah, Khabar and Athaar must be construed in the light of the aforementioned connotations and the other surrounding circumstances and causes which are deemed relevant to its understanding.

\section{References}

Al-Nisā, v.80.

2 Musafa Al-Sibaaïe, Al-Sunnah Wa Makanatuhā fì Al-Tashrī, AlMaktaba-tul- Al- Islamï, Dar-ul-Aurāq, 2011, p.53.

3 Ibid.

4 Ibid.

5 Ibrãhīm Bin Mūsā Al-Lahmî Al-Shátbī, Al-Muwafaqāt Fī Usūl-alShàrīah, Dar-ul-Kutub-ul-Ilmïah,2004,vol. 4, p. 504.

6 Walī-ud-Dīn Abi Abdillah Al-Khatīb Al-Umrī Al- Tabraizī, Mishtãt-ulMasābīh, Makabah Muhammadiah, Chīchah Watn̄̄, 2005, Vol.2, P. 446.

7 Ibid-Vol.2 p.47.

8 Muslim Bin Al-Hajjaj Al-Qushairī, Al- Musnad Al-Sahīh Al- Mukhtasar Bi Naqli-lil-Adl Anil Adli ila Rasùl-il-Allahi Sallahu Alaihi Wa Sallama, Dar-ul-Ihyā-e- Al- Turath-il- Arabi, Beirut, 1999, Vol. 3, PP. 804-805.

9 Ibid vol. 3 p.927.

10 Ibid vol. 3 p.944.

11 Ibid vol.8 p.1.

12 Muhammad Bin Ismāīl Al- Bukharī, Al- Jamī Al- Musnad Al-Sahīh, AlMukhtasar Min Umōri Rasūli-llahi Sallahu Alaihi Wa Sallama Wa Sunanihi Wa Ayyamihi, Daru Tœqi Al- Najati, 1422H, Vol. 1, P. 113.

13 Ibid pp. 438-439.

14 Ibid, 2, PP. 358-359.

15 Muslim Bin Al-Hajjaj Al-Qushairī, Vol, 3, P. 944.

16 Al- Mā'idah, V. 67.

17 Ibrãhīm Bin Mūsā Al-Lahmî Al-Shátbī, Vol. 4, P. 41.

18 Ibid, Vol. 4, PP. 39-45.

19 Muslim Bin Al-Hajjaj Al-Qushairī, Vol. 3, P. 944.

20 Abul Hassan Seyyid-ud-Din Al- Amdī, Al-ihkām Fī Usūl-il- Ahkām, AlMaktab-ul- Islāmī, Beirut, 1998, Vol. 1, P. 97.

21 Habīb-ur-Rehmân Siddique, Usūl-ul-Fiqh, Idarah Islãmiyat, Lāhore, 2000, P. 61.

22 Ibid.

23 Muhammad Bin Abi Bakr Ibn-ul-Qayyim, I'lām-ul- Muwaqqi'īn Ån Rabb-il-Âlamīn, Dar-ul-Kutub Ilmīya, Beirut, 1991, Vol. 1, P. 202. 
${ }^{24}$ Sád-ud-Din Mâsōd Ibn e Umar Taftāzānī, Al- Talvī Ala-Tãuzīh, Dar-ulKutub Ilmīya, Beirut, 1990, Vol. 2, P. 2.

25 Ibid.

${ }^{26}$ H. A. R. Bibb, Muhammedanism, University of Michigan Library, 1956, PP. 61-62.

27 J. Schacht, PreIslamic Background and early devolvement of Jurisprudence, treaties in Law in the Middle East, PP. 34-35.

28 J. A. Guillaume, Islam, Pelican Books, 1954, PP. 92-93.

29 Majid Khaddurī, Nature and Source of Islamic Law in the middle East, article in a symposium on Muslim Law in the George Washington Law Review, Vol. XXII, Oct. 1953.

30 Kenneth Cragg, The Call of Minaret, New York, 1956, P. 114.

31 C.A. Nallino, Lecture on the Influence of Roman Law on Islamic Law, TR. By Dr. M. Hammidullah, Islamic Review Working, Dec. 1933, P. 85.

32 Ma'roof Dawālibī, Al- Madkhal Fi Al- Haqūq Al- Rūmaniyah, Damascus, 1948, PP. 52-81.

33 H. A. R. Bibb, Muhammedanism, P. 73.

34 Al- Bukharī, Kitab-ul-Ilm, Babu Fazlil Ilmi.

35 Hadīth, an Arabic word Literally Meaning "Saying" is used as a synonym for the Legal Expression "Sunnah".

36 Abū Abdillah Muhammad Bin Sād, Al- Tabqāt-ul-Kubrā, Maktabat-ulUlūm Wa Al-Hikam, Al- Madīnat-ul-Munawwārah, 1408H, Vol. 2, P. 125.

37 Al- Bukharī, Kitab-ul-Ilm, Babu Fazlil Ilmi.

38 M. Hammidullah, Early History of the Compilation of the Hadīth, article in Islamic Review, May 1949.

39 Al-Bukharī, Vol. 2, Hadīth, 1084-1085.

40 H. A. R. Bibb, Muhammedanism, P. 64.

41 Ibid.

${ }^{42}$ Ibid, P. 66.

${ }^{43}$ C. A. Nallino, Lecture on the Influence of Roman Law on Islamic Law, Review, 1933, P. 9.

44 H. A. R. Gibb, Muhammedanism, P. 66.

45 Ibd, P. 65.

46 Ibn e Duræd Maliki, Al- Jamharah, Dar-ul-ilm LilMalābīn, 1987, P. 95.

47 Abū Nasr Bin Hammad Al- Jouharī, Taj-ul-Lughah Wa Sihah-ul-Arabia, Dar-ul-Kutub Al-Ilmiyyah, Beirut, 1990, Vol. 5, P. 2139.

48 Adul Hassan Ahmed Bin Farris Bin Zakariyya, Mùjamu Maqāīes AlLughah, Dar-ul-Fikr, Beirut, 1979, Vol. 3, P. 61.

49 Rāghib Isfihān̄ī, Al- Mufradāt Fī Gharīēb-il-Qurān, Dar-ul-Qalam, Beirut, 1412H, P. 242.

50 Zemåkhsharī, Asās-ul-Bàlāghåh, Dar-ul-Kutub, Beirut, 1998, P. 221. 
51 Ibn e Athīr Al-Jazrī, Al-Nihāyah Fī Gharīb Al-Hadīth Wa Al- Athår, AlMaktabat-ul-Ilmīyah, Beirut, 1979, Vol. 2, P. 201.

52 Muhammad Bin Abi Bakr Ibn-ul-Qayyim, I'lām-ul- Muwaqqi'īn Ån Rabb-il-Âlamīn, Vol. 2, P. 101.

53 Jalāl-ud-Din Al-Såyōtī, Al-Itqān Fī Ulùmi Al-Qurān, Al-Hæ'at-ulMisriah Lil Kutub, 1974, Vol. 2, P. 54. Ibn e Abdul Bārr, Al-Jamî Bàyānil-Ilmi Wa Fazlihi, Dar o Ibn Al- Jaõzī, Dammam, 1994, Vol. 1, P. 52.

54 Al jameha bayan al ilm wa fadlihi page-52.

55 Abdul Rehmān Ibn e Jouzī, Al- Manāqî̉b Amērīl Müminēn Umãr Bin AlKhattāb, Shakur Publications, 2014, P. 80.

56 Muhammad Ujjāj Al- Khatēb, Al- Sunnah Qab-al-Tadwēn, Maktabah Wahbah, Al-Qāhirah, 1988, PP. 15-16.

57 Ibd PP. 17-18.

58 Al-Imām Ahmad Bin Hambàl, Al- Musnad, Mu'assisat-ur-Risalah, Beirut, 2009, V. 6, P.270.

59 Sád-ud-Din Mâsōd Ibn e Umar Taftāzānī, Al- Talvī Ala-Tãuzīh, Vol. 2, P. 30 .

60 Muhammad Khizri Bik, Usūl-ul-Fiqh, Al-Maktabat-ut-Tijārïah, Mîsr, 1969, P. 275.

61 Hassan Ahmad Al-Khatīb, Fiqh-ul-Islam, Dar-ul-Qalam, Beirut, 2007, P. 69.

62 Al- Jazïrī, Jōùjīh-ul-Anzār, P. 3.

63 Ibn-ul-Lihām Al-Hambálī, Al-Qawā'id-ul-Usūlīyah, Maktabat-ul-Asriah, 1999, P. 78.

64 Ibn e Taīmiah, Risalatun Fi Usūl-il-Dēn, Dar-ul-Qalam, Beirut, 1980, P. 16.

65 Safî̀u-ud-Dēn, Al- Hambålī, Qawā'id-ul-Usūl, Al-Turāthal-ul-Islāmi, Makkah, 1997, P. 91.

66 Ali Bin Muhammad Al-Jurjān̄̄, Kitāb-ut-Tarīfāt, Dar-ul-Kutub AlIlmiyyah, Beirut, 1983, P. 82.

67 Muhabb-ul-Llah Bihari, Musallam-us-Subōt, Jamia Sirajiah, FSD, Vol. 2, P. 66.

68 Al- Baidhāvī, Minhāj-ul-Usûl, P. 61.

69 Al-Hussāmi, Kitab-ut-Tahqēq, Lakhnavō, P. 127.

70 Abdul Hayē Lakhnavī, Nuzhät-ul-Khawātir, Dakkan, Vol. 1, P. 226.

71 Mulla Jēvān, Nōr-ul-Anwār, Lakhnavō, P. 173.

72 Ibn e Hazm, Al- Undulusī, Al-ihkām Fī Usūl-il-Ahkām, Dar-ul-Afāq, Beirut, 1983, Vol. 2, P. 6.

73 Al-Shatibī, Al-Muwafaqāt Fī Usūl-al-Shàrīah, Vol. 4, P. 3. 